\title{
Characterization of flaxseed and flaxseed oil as edible oil resources
}

\author{
O Jun Kwon* \\ Gyeongbuk Institute For Regional Program Evaluation, Gyeongsan 38542, Korea
}

\section{아마인 및 아마인유의 유지자원으로서의 특성}

\author{
권오준* \\ (재)경북지역사업평가단 평가팀
}

\begin{abstract}
The objective of this research was to find out the potential value of flaxseed as a dietary supplement as well as an edible oil resource. The characteristics of yellow flaxseed oil and brown flaxseed oil were compared to check which oil is better in the aspects of cooking purpose and of nutritional value. The quality of flaxseed oil was evaluated based on the composition of fatty acid, the content of phenolic compounds and the anti-oxidant activity. The total phenolics of yellow flaxseed oil and brown flaxseed oil were $10.78 \pm 0.46$ and $29.88 \pm 3.25 \mathrm{mg} / 100 \mathrm{~g}$, respectively. Their y-tocopherol contents were 20.59 and $17.94 \mathrm{mg} / 100 \mathrm{~g}$, respectively. Contents of linolenic acid were 56.60 and $31.38 \%$ and oleic acid were 18.24 and $39.16 \%$, respectively. Yellow flaxseed oil showed higher ratio of unsaturated fatty acid than brown flaxseed oil. However, brown flaxseed oil showed higher electron-donating abilities than brown flaxseed oil, which might be due to its higher content of phenolic compounds. In conclusion, flaxseed has a great potential as a good edible oil resource due to its high content of unsaturated fatty acid and anti-oxidant activity.
\end{abstract}

Key words : yellow flaxseed oil, brown flaxseed oil, y-tocopherol, linolenic acid, oleic acid

\section{서 론}

아마인(Linum usitatissimum)은 고대부터 재배되어진 오 랜 역사를 지닌 작물로서 기원전 6,000년경 티그리스강과 유프라테스강 유역의 고대농업사회에서 재배되었다(1). 전 통적으로 아마인에서 추출한 아마인유는 주로 페인트의 희석제나 리놀륨으로 이용되었고, 아마인유의 부산물은 사 료 등으로 이용되었으며, 고대의 그리스나 로마에서는 일 찍이 식품의 재료로 이용하였다. 최근에는 건강을 위해 아 마인이나 압착 아마인이 빵이나 시리얼, 음료로 이용되어 지고 있으며, 주요 경작지는 캐나다가 지배적이고, 중국, 인도, 미국 등의 지역에서도 재배되고 있다 $(2,3)$.

*Corresponding author. E-mail : ojkwon@irpe.or.kr Phone : 82-53-818-9504, Fax : 82-53-818-9504

Received 28 February 2016; Revised 3 August 2016; Accepted 8 August 2016.

Copyright (C) The Korean Society of Food Preservation. All rights reserved.
최근 아마씨는 미국과 캐나다에서 건강증진 식품으로 많은 각광을 받고 있다. 아마씨의 다양한 건강증진 효능에 대한 유효 활성물질로는 페놀성 화합물인 리그난류가 대표 적인 물질이며 항산화 활성에 관여하는 것으로 알려져 있 다. 특히 아마인의 경우 secoisolariciresinol diglucoside (SDG)이 대표적인 리그난으로서(4) 항산화 활성뿐만 아니 라 항암, 당뇨병 및 동맥경화 예방에도 효과가 있다고 알려 지고 있다(5-7). 또한, 아마인의 대표적인 페놀산으로는 trans-ferulic(46\%), trans-sinapic(36\%), $\rho$-coumaric(7.5\%), trans-caffeic(6.5\%) 등이 알려져 있다(8). 아마인의 아미노 산 중 glutamine의 경우 immune system에 도움을 주며(9), arginine은 심장질환 예방에 효과가 있어(10) 유지의 추출 후 생기는 아마인박(linseed cake)의 활용이 기대된다.

현재 우리나라의 대표적인 유지자원은 참깨와 들깨로서, 이를 이용한 참기름과 들기름은 독특한 향미 외에도 토코페 롤과 리그난류의 산화방지제를 함유하고 있는 유용한 기능 식품이다. 또한 oleic acid와 linoleic acid 같은 불포화지방산 을 다량 함유하고 있어 영양학적으로도 우수한 유지로서, 
마가린 및 쇼트닝 등의 조리유에도 이용되고 있다 $(11,12)$. 이에 본 연구에서는 아마인과 기존 유지작물의 일반성분 및 유용성분을 분석하였으며, 추출유의 지방산 조성 및 토 코페롤 함량 등 영양학적 가치와 경제성을 고려한 아마인의 산업적 가치를 비교, 검토하고자 하였다.

\section{재료 및 방법}

\section{실험재료}

본 실험에 사용된 아마인은 경상북도 농업기술원 생물자 원연구소에서 제 공받았으며(2011년), 참깨 및 들깨는 안동 시에서 재배된 것을 구입하였다. 각각의 유지는 n-Hexane 을 이용하여 상온에서 2 시간 동안 교반 추출하였으며, 추출 후 회전식 감압농축기를 이용하여 $37^{\circ} \mathrm{C}$ 에서 감압농축하였 다. 농축된 시료는 $-20^{\circ} \mathrm{C}$ 에서 보관하여 실험에 이용하였다.

\section{일반성분 분석}

일 반성분은 $\mathrm{AOAC}$ 법에 준하여 분석하였다. 수분은 10 $5{ }^{\circ} \mathrm{C}$ 상압건조법, 회분은 회화법, 지질은 Soxhlet 추출법, 단백질은 Kjeldahl법을 이용하였고, 조섬유는 HennebergStohmann법을 개량한 $\mathrm{AOAC}$ 법으로 측정하였다. 당질 함량 은 $100 \mathrm{~g}$ 중에서 수분, 단백질, 지질, 조섬유, 회분 함량을 감한 값으로 하였다.

\section{아미노산 조성 분석}

지질을 제거한 시료 약 $0.5 \mathrm{~g}$ 을 취한 후 $6 \mathrm{~N} \mathrm{HCl} 20$ $\mathrm{mL}$ 을 가하여 $110^{\circ} \mathrm{C}$ 에서 12 시간 가수분해 시켰다. 가수분해 시료 $0.2 \mathrm{~mL}$ 에 $100 \mathrm{mM}$ phenyl isothiocyanate(in acetonitrile) $0.1 \mathrm{~mL}$ 와 $1 \mathrm{M}$ triethylamine(in acetonitrile) $0.1 \mathrm{~mL}$ 를 혼합한 후 1 시간 정도 상온에서 반응시키고 시료의 추출을 위하여 $0.4 \mathrm{~mL}$ hexane 용액을 첨가한 후 용액이 분리되도록 10 분간 방치한 후 분석시료로 이용하였다(13). 사용한 기기는 $\mathrm{ACE}$ $5 \mathrm{C}_{18}$ column $(250 \times 4.6 \mathrm{~mm})$ 을 장착한 LC-20A Prominence HPLC system(Waters 2695, waters Co., Miliford, MA, USA) 을 이용하였고 column 온도는 $25^{\circ} \mathrm{C}$ 로 유지 하였다. 용매 조성은 $\mathrm{A}$ 용매는 $10 \mathrm{mM}$ sodium phosphate buffer(pH 7.0)이 고 B용매는 acetonitrile를 사용 하였으며, 용매의 흐름 속도 는 $1.0 \mathrm{~mL} / \mathrm{min}$ 로 하여 $\mathrm{A} / \mathrm{B}=95 / 5 \rightarrow 65 / 35(\mathrm{v} / \mathrm{v})$ 의 용매 구배 로 40 분간 분리 하였다. 검출기는 UV detecter (SPD-20A, waters Co., Miliford, MA, USA)로 $254 \mathrm{~nm}$ 에서 측정하였다.

\section{유지의 지방산 조성 분석}

시료의 지방산 조성은 gas chromatography(GC)에 의한 정량법에 따라 실시하였다 $(14,15)$. 추출한 지질의 지방산 조성은 정제된 지질을 각각 $0.1 \mathrm{~g}$ 씩 취하여 $0.5 \mathrm{~N} \mathrm{NaOH}-$ methanol 용액으로 가수분해 하여, $\mathrm{BF}_{3}$-methanol로 methyl ester화 시킨 다음 GC(Hewlett packard 6890, USA)로 분석하 였다. $\mathrm{GC}$ 에서 분리된 각 지방산 methyl ester의 면적과 총면 적에 대한 각 peak면적을 이용하여 각 지방산들의 조성비를 백분율로 표시(\%) 하였다. $\mathrm{GC}$ 분석 조건은 Table 1 과 같으 며, 표준품으로는 Supelco ${ }^{\mathrm{TM}} 37$ component FAME Mix를 사용하였다.

Table. 1. GC specification and operating conditions for the analysis of fatty acid

\begin{tabular}{cc}
\hline Requester & Condition \\
\hline Instrument & Hewlett packard 6890, USA \\
Column & HP-FFAP (Polyethylene Glycol) \\
& $: 30 \mathrm{~m} \times 0.25 \mathrm{~mm}$ id $\times 0.25 \mu \mathrm{m}$ film \\
Detector & Flame Ionization Detector (FID) \\
Split mode & Split ratio $1: 100$ \\
Inject volume & $1 \mu \mathrm{L}$ \\
Carrier gas & Nitrogen, flow rate at $1 \mathrm{~mL} / \mathrm{min}$ \\
Injection port & $220^{\circ} \mathrm{C}$ \\
Detection port & $240^{\circ} \mathrm{C}$ \\
& Initial temp. $160^{\circ} \mathrm{C}$ at $1 \mathrm{~min}$ \\
Oven temp. program & Temp. gradient $2{ }^{\circ} \mathrm{C} / \mathrm{min}$ \\
& Final temp. $220^{\circ} \mathrm{C}$ at $10 \mathrm{~min}$ \\
\hline
\end{tabular}

\section{토코페롤 측정}

토코페롤의 함량 측정은 Yen 등(16)의 방법을 변형하여 실험하였다(17). 시료유 $0.5 \mathrm{~g}$ 을 $2.5 \mathrm{~mL}$ 의 methanol에 추출 한 후, 원심분리 하여 상등액을 채취한 뒤 유기용매를 완전 히 제거하였다. 유기용매가 제거된 시료에 $2.5 \mathrm{~mL}$ 의 $\mathrm{CH}_{3} \mathrm{CN}: \mathrm{MeOH}(85: 15)$ 용매를 이용하여 시료를 녹인 후, 원 심분리 하여 상등액을 토코페롤 측정 시료로 사용하였다. 사용한 기기는 ACE $5 \mathrm{C}_{18}$ column $(4.6 \mathrm{~mm} \times 250 \mathrm{~mm})$ 을 장착 한 LC-20A Prominence HPLC system(Waters 2695, waters Co., Miliford, MA, USA)을 이용하였고 column온도는 $25^{\circ} \mathrm{C}$ 로 유지 하였다. 용매 조성은 $\mathrm{CH}_{3} \mathrm{CN}: \mathrm{MeOH}(85: 15)$ 로 20 분 간 분리 하였다. 검출기는 UV detecter(SPD-20A, waters Co., Miliford, MA, USA)로 $298 \mathrm{~nm}$ 에서 측정하였다.

\section{유지의 총 폴리페놀 함량}

시료의 총 페놀 함량은 Satue 등(18)의 방법에 따라 추출 한 후 Folin-ciocalteu 법(19)을 변형하여 함량을 측정하였다. 즉, 먼저 시료를 각각 $2 \mathrm{~g}$ 씩 취하여 $\mathrm{n}$-Hexane $5 \mathrm{~mL}$ 에 녹인 후 $80 \%$ methanol $10 \mathrm{~mL}$ 를 가하여 페놀성 물질을 3 회 반복 추출하였다. 이 추출물에 $\mathrm{n}$-hexane $10 \mathrm{~mL}$ 를 가하여 잔존하 는 유지성분을 제거한 후 무수황산나트륨을 이용하여 수분 을 제거하였다. 각각의 분리된 $80 \%$ methanol 층을 감압농축 기를 이용하여 용매를 완전히 제거하였다. 용매가 제거된 
각각의 추출물들은 에탄올에 녹여 총 페놀 함량 측정 시료 로 사용하였다. 총 페놀 함량은 시험관에 시료를 $0.5 \mathrm{~mL}$ 채취하고 $1 \mathrm{~N}$ Folin-ciocalteu 시약을 $0.5 \mathrm{~mL}$ 를 첨가하여 3 분 후 $2 \%$ sodium carbonate anhydrous 포화용액 $10 \mathrm{~mL}$ 를 첨가하여 1 시간 동안 반응시켰다. UV/Visible spectrophotomer (SpectraMax M2, Molecular Devices, Hercules, USA)를 이용 하여 $750 \mathrm{~nm}$ 에서 여과 된 반응물의 흡광도를 측정하여 총 페놀 함량을 구하였다. 표준물질로는 tannic acid (Sigma-Aldrich Co., St. Louis, MO, USA)를 사용하였다.

\section{전자 공여능 측정}

시료의 전자 공여능은 Lee 등(20)의 방법을 변형하여 항 산화물질에 의한 2,2-diphenyl- $\beta$-picrylhydrazyl(DPPH) 라 디컬 소거 효과를 측정하였다. 시험관에 $2.7 \mathrm{~mL}$ 의 $0.15 \mathrm{mM}$ $\mathrm{DPPH}$ 용액과 농도별로 조제한 시료 $0.8 \mathrm{~mL}$ 를 넣고 실온에 서 15 분 방치한 후 $525 \mathrm{~nm}$ 에서 UV/Visible spectrophotomer (SpectraMax M2, Molecular Devices, Hercules, USA)로 흡광 도를 측정하였다. 대조구로는 메탄올을 사용하였으며, 그 값은 다음 식에 의하여 계산하였다.

$$
\text { 전자공여능 }(\%)=\left(1-\frac{\text { 실험구 측정치 }}{\text { 대조구 측정치 }}\right) \times 100
$$

\section{결과 및 고찰}

\section{일반성분 분석}

각각의 아마인을 분쇄하여 일반성분을 조사한 결과는 Table 2 와 같다. 수분과 탄수화물은 $37 \%$ 정도를 차지하고 있으며 조지방은 참깨나 채종유 원료 등의 $40 \%$ 이상의 유지 함량에는 못 미치나 대두의 $20 \%$ 보다는 높은 $35 \%$ 내외인 $35.33 \%$ 와 $36.16 \%$ 인 것으로 나타나 유지 자원의 활용이 가 능하리라 사료된다. 또한 단백질은 $25.60 \%$ 와 $22.59 \%$ 로 두 시료간에 큰 차이는 없었으며, 회분의 경우 $2.50 \%$ 와 $3.54 \%$ 으로 갈색 아마인이 다소 높은 함량을 나타내었다.

Table. 2. Proximate composition of Flaxseed

\begin{tabular}{ccc}
\hline Composition $(\%)$ & Yellow flaxseed & Brown flaxseed \\
\hline Moisture & $7.12 \pm 0.23^{1)}$ & $7.53 \pm 0.38$ \\
Crude protein & $25.60 \pm 0.87$ & $22.59 \pm 3.15$ \\
Crude fat & $35.33 \pm 5.59$ & $36.16 \pm 2.46$ \\
Crude ash & $2.50 \pm 0.04$ & $3.54 \pm 0.06$ \\
Crude fiber & $7.07 \pm 0.07$ & $3.16 \pm 0.12$ \\
Carbohydrate & 22.38 & 27.02 \\
Starch & $0.58 \pm 0.61$ & $9.80 \pm 1.24$ \\
\hline
\end{tabular}

${ }^{1)}$ Each value is expressed as the mean $\pm \mathrm{SD}$ of triplicate determinations.
아미노산 조성 분석

아마인의 단백질은 관상동맥질환, 신장질환 및 암 등에 효과가 있다고 알려져 있으며(21) 이러한 아마인의 아미노 산 조성을 분석한 결과 황색과 갈색 아마인의 아미노산 조성 차이는 없었으며, 주요 구성 아미노산은 glutamine, glycine, arginine 등이었으나 cystine, methionine 등의 함량 은 매우 낮게 나타났으며(Table 3), 필수 아미노산 함량은 전체 아미노산의 $31 \%$ 수준으로 이는 참깨박의 $31.5 \%$ 와 유사한 함량을 나타내었다(22). Chung 등(23)의 연구에 따 르면 아마인의 주요 아미노산은 arginine, glutamine, asparagine으로 유사한 결과를 보였다. Czarnecki와 Krichevsky (24), Park과 Leipa(25)의 연구에 따르면 lysine/arginine ratio 에 따라 고콜레스테롤혈증 및 동맥경화증에 영향을 준다고 알려져 있으며, 아마인의 비율이 0.37 로서 콩 및 카놀라의 0.88 보다 낮아 더 좋은 효과를 나타낸다고 보고하였고 본 연구 결과 황색 및 갈색 아마인 모두 0.35 수준으로 나타났 다.

Table. 3. Compositions of amino acid in yellow flaxseed and brown flaxseed

\begin{tabular}{ccc}
\hline \multirow{2}{*}{ Amino acid } & \multicolumn{2}{c}{ Compositions $(\mathrm{mg} / \mathrm{g})$} \\
\cline { 2 - 3 } Asp & Yellow flaxseed & Brown flaxseed \\
Glu & 8.40 & 8.14 \\
Ser & 17.53 & 16.91 \\
Gly & 6.36 & 6.29 \\
His & 12.38 & 12.19 \\
Arg & 3.16 & 3.09 \\
Thr & 10.84 & 10.98 \\
Ala & 4.39 & 4.20 \\
Pro & 7.17 & 7.25 \\
Tyr & 7.67 & 7.19 \\
Val & 3.54 & 3.29 \\
Met & 3.68 & 3.18 \\
Cys & 2.01 & 2.24 \\
Ile & 1.99 & 2.08 \\
Leu & 2.98 & 2.71 \\
Phe & 7.88 & 7.05 \\
Lys & 6.09 & 5.98 \\
Total & 3.79 & 3.88 \\
\hline & 109.85 & 106.65 \\
\hline
\end{tabular}

\section{유지의 지방산 조성 분석}

추출한 각각의 아마인 유지의 지방산 조성은 포화지방산 과 불포화지방산의 비율 및 조성 지방산의 함량 측면에서 큰 차이를 나타내었다(Table. 4). 황색 아마인의 경우 포화 지방산이 $10 \%$, 불포화지방산은 $90 \%$ 로서 갈색 아마인의 
포화지방산 $14 \%$, 불포화지방산 $86 \%$ 와 비교할 때 황색 아 마인유의 불포화도가 상대적으로 높은 경향을 나타내었다. 총 지질의 지방산 함량은 황색 아마인의 경우 linolenic acid 가 $56.6 \%$ 로 가장 높은 함량을 나타내었으며, 갈색 아마인 은 oleic acid가 $39.2 \%$ 로 많은 함량을 나타내었고, linoleic acid의 경우 두 종류 모두 $15 \%$ 정도의 유사한 함량을 나타내 었다. 아마인은 일반적으로 linolenic acid함량이 47 52\% 수준으로 보고되고 있지만(26) 황색과 갈색 아마인의 지방 산 조성에 대한 연구는 전무한 실정으로 본 연구의 지방산 조성 분석 결과에서 큰 차이를 나타내었다. 일반 식용유지 인 참기름은 oleic acid와 linoleic acid가 각각 $41.1 \%$ 와 $43.8 \%$ 로 나타났으며, 들기름은 oleic acid와 linolenic acid가 각각 $15.2 \%$ 와 $62.8 \%$ 수준으로 분석되었다. 따라서 다가 불포화 지방산의 산화로 악영향을 받기 쉬운 점을 고려할 때(27) linolenic acid의 함량이 높은 황색 아마인 보다는 oleic acid 의 함량이 높은 갈색 아마인이 비교적 안정성이 있는 식물 유지로서 가공적성이 우수할 것으로 사료되며, 이러한 유 지의 산화 안정성을 고려해 1990년대에 개발된 linola라는 아마인의 경우 a-linolenic acid의 함량을 $2 \%$ 이하로 낮추고, $\gamma$-linolenic acid와 linoleic acid의 함량을 $65 \sim 75 \%$ 로 높여 산화 안정성이 높은 것으로 보고되었다(28).

Table. 4. Fatty acid compositions of Oils from various sources

\begin{tabular}{ccccc}
\hline \multirow{2}{*}{ Fatty acids } & \multicolumn{4}{c}{ Compositions (\%) } \\
\cline { 2 - 5 } & $\begin{array}{c}\text { Yellow } \\
\text { flaxseed oil }\end{array}$ & $\begin{array}{c}\text { Brown } \\
\text { flaxseed oil }\end{array}$ & Sesame oil & Perilla oil \\
\hline Palmitic acid (C16:0) & 5.32 & 7.18 & 8.36 & 6.55 \\
Stearic acid (C18:0) & 3.66 & 6.59 & 5.52 & 2.57 \\
Oleic acid (C18:1) & 18.24 & 39.16 & 41.09 & 15.17 \\
Linoleic acid (C18:2) & 16.26 & 15.62 & 43.77 & 12.89 \\
Linolenic acid (C18:3) & 56.60 & 31.38 & 1.27 & 62.83 \\
USFA ${ }^{11} /$ SFA $^{2)}$ & 10.14 & 6.26 & 6.21 & 9.97 \\
\hline
\end{tabular}

${ }^{1)}$ USFA, Unsaturated fatty acids.

${ }^{2)}$ SFA, Saturated fatty acids.

\section{토코페롤 함량}

각각의 추출된 유지들의 $\mathrm{\gamma}$-토코페롤과 $\mathrm{a}$-토코페롤의 함 량을 비교분석한 결과는 Table 5에 나타내었다. 토코페롤은 고도 불포화지방산의 산화를 억제하는 기능을 가지고 있어 유지의 안정화에 있어 토코페롤의 함량은 중요한 요소이 며, 본 연구 결과 $\mathrm{\gamma}$-토코페롤은 황색 아마인과 갈색 아마인 이 각각 $20.59,17.94 \mathrm{mg} / 100 \mathrm{~g}$ 으로 대조구로 시험한 참깨의 $13.82 \mathrm{mg} / 100 \mathrm{~g}$ 보다는 높았지만 들깨의 $30.10 \mathrm{mg} / 100 \mathrm{~g}$ 보단 낮은 함량을 보였으며, $\mathrm{a}$-토코페롤의 경우 들깨에서 1.42 $\mathrm{mg} / 100 \mathrm{~g}$ 의 함량을 나타내었지만 다른 유지에서는 검출되 지 않았다. Oomah 등(29)의 연구에서는 아마인씨의 토코페 롤 함량이 $9.3 \mathrm{mg} / 100 \mathrm{~g}$ 로서 이중 96 98\%가 $\gamma$-토코페롤이
라고 보고하였다. 본 연구에서는 황색 아마인과 갈색 아마 인씨에서 각각 $7.3,6.5 \mathrm{mg} / 100 \mathrm{~g}$ 로서 다소 차이는 있었지만 이는 추출 방법의 차이로서 압착과 열을 가하게 되면 기름 유출과 토코페롤 등의 유용물질의 추출이 향상되는데, 기 름 추출율과 지용성 비타민 추출율이 비례하기 때문인 것으 로 사료된다(30). 이러한 공정은 유지의 열에 의한 열화로 인하여 산화안정성은 낮아질 것으로 생각된다.

Table. 5. Tocopherols contents of yellow flaxseed oil, brown flaxseed oil, Sesame oil and Perilla oil

\begin{tabular}{ccccc}
\hline \multirow{2}{*}{ Tocopherols } & \multicolumn{4}{c}{ Content (mg/100 g) } \\
\cline { 2 - 5 } & $\begin{array}{c}\text { Yellow } \\
\text { flaxseed oil }\end{array}$ & $\begin{array}{c}\text { Brown } \\
\text { flaxseed oil }\end{array}$ & Sesame oil & Perilla oil \\
\hline z-Tocopherol & 20.59 & 17.94 & 13.82 & 30.10 \\
a-Tocopherol & $\mathrm{ND}^{1)}$ & $\mathrm{ND}$ & $\mathrm{ND}$ & 1.42 \\
\hline
\end{tabular}

${ }^{1)}$ Not detectable.

\section{총 폴리페놀 함량}

황색 아마인, 갈색 아마인, 참깨 및 들깨에서 추출한 지질 의 총 폴리페놀 함량을 측정한 결과 각각 $10.78 \pm 0.46$, $29.88 \pm 3.25,11.28 \pm 0.35$ 및 $15.52 \pm 2.24 \mathrm{mg} / 100 \mathrm{~g}$ 으로 갈색 아마인이 가장 높은 총 폴리페놀 함량을 나타내었다(Fig. 1). 갈색 아마인은 황색 아마인보다 약 3 배, 참깨보다 약 2.6 배를 나타냈으며, 들깨보다는 약 2 배 정도 높은 총 폴리 페놀 함량을 나타내었다. 따라서 갈색 아마인의 총 폴리페 놀 함량이 가장 높게 나타난 결과로 보아서 갈색 아마인의 추출 유지가 산화 안정성이 가장 클 것으로 판단된다. 또한 식품의 건강증진효능에 대한 원인물질로서 페놀성 화합물 의 가치가 높게 평가 되므로 이러한 기능성 측면에서도 갈색 아마인의 가치가 높이 평가 될 것으로 판단된다. $\mathrm{Kim}$

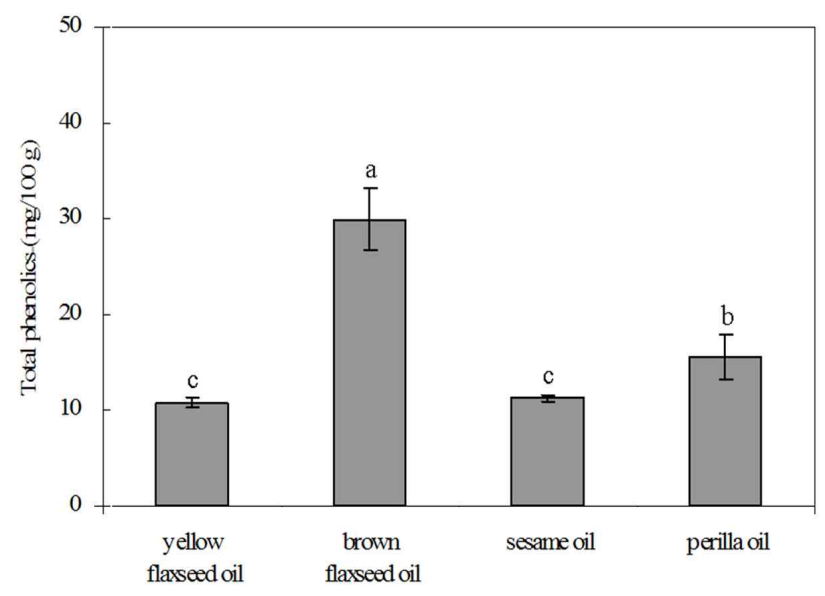

Fig. 1. Total phenolics $(\mathrm{mg} / 100 \mathrm{~g})$ of yellow flaxseed oil, Brown flaxseed oil, sesame oil and perilla oil.

Values given are the mean of three replicates $\pm \mathrm{SD}$.

${ }^{a c}$ Means with the different letters are significantly different $(p<0.05)$ by Duncan's multiple range test. 
등(31)은 이들 페놀성 화합물은 정제 및 탈색 등의 공정에 따라 현저한 변화를 일으키며 가열 온도의 증가에 따라 더욱 높아진다고 보고하였다.

\section{전자 공여능 측정}

각 추출유의 전자 공여능을 2,2-diphenyl- $\beta$-picrylhydrazyl $(\mathrm{DPPH})$ 라디칼의 소거 정도에 따라 비교하여 측정한 것을 Fig. 2로 나타내었다. $10 \sim 5,000 \mathrm{mg} \%$ 범위의 농도에 따른 전자 공여능의 변화를 살펴본 결과 $10 \mathrm{mg} \%$ 에서는 시료간 의 유의적인 차이를 나타내지 않았지만, $100 \mathrm{mg} \%$ 의 농도에 서부터 시료간의 차이를 나타내었다. $1,000 \mathrm{mg} \%$ 농도의 경우 갈색 아마인이 $40.96 \pm 0.14 \%$ 로서 유의적으로 높은 값 을 나타내었고 황색 아마인과 들깨가 각각 $31.74 \pm 0.77$, $30.81 \pm 0.58 \%$ 로서 유사하게 나타났으며, 참깨가 $22.78 \pm$ $0.47 \%$ 로서 가장 낮은 활성을 나타났다. $2,500 \mathrm{mg} \%$ 의 농도 의 경우에도 갈색 아마인과 황색 아마인이 각각 $77.81 \pm 0.61$, $66.90 \pm 2.12 \%$ 로서 다른 유지 작물에 비해 높은 활성을 보였 으며, 이러한 결과는 토코페롤 함량과 폴리페놀 함량과 유 사한 경향을 보여 식물유지 자원으로서의 가치가 우수한 것으로 생각 된다.

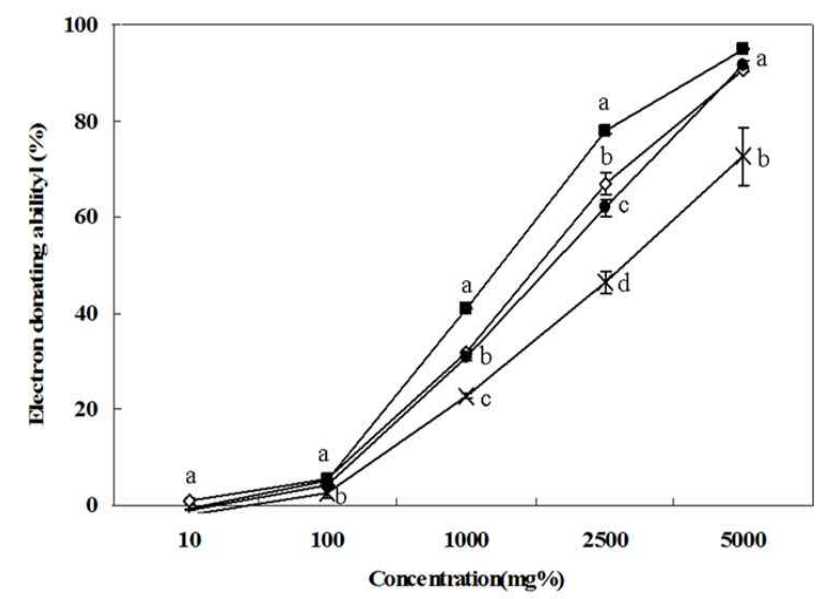

Fig. 2. Electron donating abilities of yellow flaxseed oil, Brown flaxseed oil, sesame oil and perilla oil.

Values given are the mean of three replicates \pm SD.

${ }^{\text {a-d }}$ Means with the different letters are significantly different $(\mathrm{p}<0.05)$ by Duncan's multiple range test.

$->$-, yellow flaxseed oil;

brown flaxseed oil; -

-, perilla oil; -X-, sesame oil.

\section{요 약}

황색 아마인과 갈색 아마인의 일반성분 분석과 아미노산 조성, 지방산 조성, 토코페롤 함량, 총 폴리페놀 함량 및 전자 공여능을 측정하여 각 유지들의 특성을 비교하였다. 일반성분의 경우 수분과 탄수화물은 $37 \%$ 정도를 차지하고 있으며 조지방은 $35 \%$ 내외로 대두의 $20 \%$ 보다는 높은 함량 을 나타내었다. 아마노산 조성은 황색과 갈색 아마인의 차
이는 없었으며 주요 구성 아미노산은 glutamine, glycine, arginine 등이었고, 지방산 조성의 경우는 두 아마인의 지방 산 조성에 차이가 있으며 황색과 갈색 아마인의 linolenic acid와 oleic acid의 함량은 각각 $56.60,31.38$ 과 $18.24,39.16$ 으로 나타나 갈색 아마인이 황색 아마인보단 산화 안정성이 우수할 것으로 생각된다. $\gamma$-토코페롤의 경우는 황색 아마인 이 $20.59 \mathrm{mg} / 100 \mathrm{~g}$ 으로 갈색 아마인보단 높았지만 들깨의 $30.10 \mathrm{mg} / 100 \mathrm{~g}$ 에는 미치지 못했다. 총 폴리페놀은 황색 및 갈색 아마인이 각각 $10.78,29.88 \mathrm{mg} / 100 \mathrm{~g}$ 으로 갈색 아마인이 높은 함량을 나타냈으며, 전자 공여능 또한 2,500 $\mathrm{mg} \%$ 의 농도에서 갈색 아마인이 $77.81 \%$ 으로 가장 좋은 활 성을 나타냈다. 따라서, 황색 아마인과 비교하여 갈색 아마 인이 유지의 산화안정성 및 저장성이 우수할 것으로 생각되 며, 기존 참기름 및 들기름과 비교하여서도 영양학적인 측 면과 산업적인 가치가 높다고 할 수 있다.

\section{References}

1. Oates J (1979) Babylon. Thames and Hudson Ltd., London, p 20-23

2. Muir AD, Westcott ND (2000) Quantitation of the lignan secoisolariciresinol diglucoside in baked goods containing flax seed or flax meal. J Agric Food Chem, 48, 4048-4052

3. Siegenthaler (1994) The use of flaxseed in Ethiopia. Proceedings of the 55th Flax Institute of the United States of America. Flax Institute of the United States, Fargo, North Dakota, p143-149

4. Frankel EN (1996) Antioxidants in lipid foods and their impact on food quality. Food Chem, 57, 51-55

5. Johnsson P, Kamal-Eldin A, Lundgren LN, Aman P (2000) HPLC method for analysis of secoisolariciresinol diglucoside in flaxseeds. J Agric Food Chem, 48, 5216-5219

6. Lucas EA, Lightfoot SA, Hammond LJ, Devareddy L, Khalil DA, Daggy BP, Smith BJ, Westcott N, Mocanu V, Soung DY, Arjmandi BH (2004) Flaxseed reduces plasma cholesterol and atherosclerotic lesion formation in ovariectomized Golden Syrian hamsters. Atherosclerosis, 173, 223-229

7. Prasad K (1999) Reduction of serum cholesterol and hypercholesterolemic atherosclerosis in rabbits by secoisolariciresinol diglucoside isolated from flaxseed. Circulation, 99, 1355-1362

8. Saarinen NM, Warri A, Airio M, Smeds A, Makela S (2007) Role of dietary lignans in the reduction of breast 
cancer risk. Mol Nutr Food Res, 51, 857-866

9. Blenford DE (1996) Use of amino acids and peptides in sports nutrition. International Food Ingredients, 3, 20-23

10. Pszczola DE (2000) Genes and diet: the specialized role ingredients may play. Food Technol-CHICAGO, 54, 8284

11. Shahidi F, Amarowicz R, Gharbia HA, Shehata AY (1997) Endogenous antioxidants and stability of sesame oil as affected by processing and storage. J Am Oil Chem Soc, 74, 143-148

12. Yoo MA, Kim HW, Kim KH, Kang MH (2004) Antioxidant effect of brown substances separated from defatted roasted sesame dregs. Food Sci Biotechnol, 13, 274-278

13. Janssen PSL, van Nispen JW, Melgers PATA, van den Bogaart HWM, Hamelinck RLAE, Goverde BC (1986) HPLC analysis of phenylthiocarbamyl (PTC) amino acids. I. evaluation and optimization of the procedure. Chromatographia, 22, 345-350

14. KFDA (2007) Korean food code (a separate volume). Munyoungsa, Seoul, Korea, p 22-25

15. Kim BK, Lim JH, Cho YS, Park KJ, Kim JC, Jeong JW, Jeong SW (2008) Study on characteristics of cold-pressed sesame oil and virgin sesame oil. J East Asian Soc Dietary Life, 18, 812-821

16. Yen GC (1990) Influence of seed roasting process on the changes in composition and quality of sesame (Sesamum indicum) oil. J Sci Food Agric, 50, 563-569

17. Budin JT, Breene WM, Putnam DH (1995) Some compositional properties of camelina (Camelina sativa L. Crantz) seeds and oils. J Am Oil Chem Soc, 72, 309-315

18. Satue MT, Huang SW, Frankel EN (1995) Effect of natural antioxidants in virgin olive oil on oxidative stability of refined, bleached, and deodorized olive oil. J Am Oil Chem Soc, 72, 1131-1137

19. AOAC (1995) Official Methods of Analysis. 16th ed, Association of Official Analytical Chemists, Arlington, VA, USA, p 16-17

20. Lee JM, Chung H, Chang PS, Lee JH (2007) Development of a method predicting the oxidative stability of edible oils using 2,2-diphenyl-1-picrylhydrazyl (DPPH). Food Chem, 103, 662-669

21. Oomah BD, Mazza G (2000) Bioactive components of flaxseed: occurrence and health benefits. In Phytochemicals and phytopharmaceuticals, Shahidi F, Ho CT (Editor), p 105-120

22. Ha JH, Kim DH (1996) Changes in the physico-chemical properties of the meals from the defatted sesame seeds at various roasting temperature and time. Korea $\mathrm{J}$ Food Sci Technol, 28, 246-252

23. Chung MWY (2001) Isolation and characterization of the major fraction of flaxseed proteins. MS Thesis, University of British Columbia, Canada, p 301-307

24. Czarnecki SK, Kritchevsky D (1992) Dietary protein and atherosclerosis. In Dietary proteins: how they alleviate disease and promote better health, Liepa GU, Bietz DC, Beynen AC, Gorman MA (Editor), Champaign: American Oil Chemists' Society, p 42-56

25. Park MS, Liepa GU (1982) Effects of dietary protein and amino acids on the metabolism of cholesterolcarrying lipoproteins in rats. J Nutr, 112, 1892-1898

26. Mazza G (1998) Functional Foods: Biochemical and Processing Aspects. Volume 1, CRC Press, USA, p 91-108

27. Waissbluth MD, Guzman L, Plachco FP (1971) Oxidation of lipids in fish meal. J Am Oil Chem Soc, 48, 420-424

28. Dribnenki JCP, McEachern SF, Chen Y, Green AG, Rashid KY (2003) Linola ${ }^{\mathrm{TM}} 2047$ low linolenic flax. Can J Plant Sci, 83, 81-83

29. Oomah BD, Kenaschuk EO, Mazza G (1997) Tocopherols in Flaxseed. J Agric Food Chem, 45, 2076-2080

30. Koizumi Y, Fukuda Y, Namiki M (1996) Effect of roasting conditions on antioxidative activity of roasted sesame seed oil. Part 1. Marked antioxidative activity of seed oils developed by roasting of oil sesame seeds. Nippon Shokuhin Kagaku Kogaku Kaisai, 43, 689-694

31. Kim HW (2000) Studies on the antioxidative compounds of sesame oils with roasting temperature. Korean J Food Sci Technol, 32, 246-251 